\title{
Sistem Kontrol Pintu Ruang Kuliah Berbasis RFID dan Arduino Terintegrasi Aplikasi Web Presensi
}

\section{College Room Door Control using RFID and Arduino Integrated with Presence Web Application}

\author{
Eko Didik Widianto ${ }^{1 *}$, Azis Masruhan ${ }^{2}$, Agung Budi Prasetijo ${ }^{3}$ \\ Departemen Teknik Komputer Fakultas Teknik Universitas Diponegoro \\ Jalan Prof. Sudharto, Tembalang, Semarang, Indonesia \\ e-mail: ${ }^{1 *}$ didik@live.undip.ac.id, ${ }^{2}$ aziz.masruhan@gmail.com, ${ }^{3}$ agungprasetijo@ce.undip.ac.id
}

\begin{abstract}
Abstrak - Makalah ini membahas pengembangan sistem otomatisasi ruangan pada kontrol pintu dan presensi kuliah untuk menambah keamanan ruangan. Sistem ini terintegrasi dengan aplikasi web dan menggunakan papan Arduino Mega 2560 sebagai pusat kontrol sistem. Sistem ini menggunakan RFID MFRC522 sebagai alat komunikasi dua arah dengan kartu RFID dan pembaca, modul ethernet shield sebagai penghubung ke jaringan internet, solenoid sebagai pengunci pintu, LCD untuk penampil notifikasi, serta RTC DS3231 sebagai pewaktu. Hasil pengujian menunjukkan, sistem mampu mencocokkan kartu tag dosen dengan data jadwal pada basis data dan mencocokkan kartu tag mahasiswa dengan data mahasiswa di mata kuliah yang terjadwal pada basis data. Jadwal akses ruang sesuai dengan jadwal kuliah yang dapat diatur melalui aplikasi web. Selain dari itu, pada aplikasi web yang dibangun dapat mengolah data presensi, jadwal, mata kuliah, mahasiswa, dosen dan kelas. Berdasarkan hasil pengujian, pembacaan kartu RFID dapat dilakukan sampai jarak $4 \mathrm{~cm}$. Penelitian ini menghasilkan sebuah sistem otomasi pintu berbasis RFID dan Arduino yang terintegrasi dengan sistem database berbasis web.
\end{abstract}

Kata kunci: Otomatisasi ruangan, Arduino, sistem presensi, RFID, kunci pintu solenoid.

\begin{abstract}
This paper presenst an automation systems for controling the door's room and lecture attendance which can enhance room security. This study build a college room control system integrated with a web application. This system uses the Arduino Mega 2560 board as the control center of the system. Furthermore, we used RFID MFRC522 as a two-way communication device with an RFID tag card and reader, an ethernet shield module that providing internet access to the network, a solenoid as a door lock, LCD for notification display, and RTC DS3231 as a timer. This system can control door access and attendance automation, and send the data to web application. The application can match the lecturer tag cards with his scheduled in the database and match students' tag cards with their data in scheduled courses. The room access schedule is in accordance to the class schedule, which can be arranged via the web application. The web application can process attendance data, schedules, courses, students, lecturers, and classes. The system can read the RFID tags up to a distance of $4 \mathrm{~cm}$.
\end{abstract}

Keywords: Room automation, Arduino Mega2560, presence system, RFID reader, solenoid lock door.

TELKA, Vol.7, No.2, November 2021, pp. 77 88

ISSN (e): 2540-9123

ISSN (p): 2502-1982 


\section{Pendahuluan}

Ruang kuliah merupakan sarana penting pada perkuliahan. Penggunaan ruang tanpa pengawasan dapat mengakibatkan hal-hal yang tidak diinginkan terjadi di ruang kuliah, seperti kerusakan barang dan kehilangan barang dalam ruang. Sistem keamaman diperlukan untuk meningkatkan keamanan ruang kuliah yang berfungsi untuk memberikan hak akses saat jam kuliah saja. Selain itu, perkuliahan juga membutuhkan presensi untuk mencatat kehadiran mahasiswa yang hadir saat kuliah.

Saat ini, pencatatan presensi mahasiswa sebagian besar masih menggunakan presensi tanda tangan atau secara manual. Hal ini menyebabkan mahasiswa kurang fokus saat persiapan perkuliahan dan kegiatannya karena harus terinterupsi tanda tangan presensi. Lebih lanjut, data presensi yang sangat banyak harus dimasukkan satu-persatu ke dalam basis data sehingga memperbesar peluang terjadinya kesalahan karena melibatkan operator untuk memasukkannya.

Teknologi pengenalan objek dapat digunakan untuk permasalahan tersebut, salah satunya adalah RFID. Beragam kajian tentang implementasi RFID ini telah dilakukan. Susanto dkk. [1] membangun sebuah sistem presensi berbasis RFID yang digunakan untuk mengurangi penggunaan kertas untuk presensi. Sistem diuji untuk pengambilan data, jarak pembacaan, dan daya tahan baterai. Selain itu, sistem ini juga menggunakan RTC untuk penjadwalan. Panggabean dan Pandi [2] serta Purwanti dan Romataliga [3] telah mengembangkan sistem presensi otomatis menggunakan RFID. Setiap nomor kartu ber-tag RFID adalah unik sehingga proses identifikasi kartu nirsentuh tersebut dapat dijadikan data kehadiran. Eko dan Bobi [4] juga merancang presensi perkuliahan dengan menggunakan teknologi RFID untuk mendukung kelancaran proses perkuliahan akademik.

Di sisi lain, sistem keamanan pengunci pintu juga telah banyak dikaji. Chamdun dkk. [5] telah mengembangkan sebuah sistem keamanan rumah. Sistem ini menggunakan sensor PIR, mikrokontroler Atmega16, sensor magnetic switch, RFID. Asad dkk. [6] mengembangkan sistem pengunci otomatis yang dapat dikontrol melalui media SMS. Sistem ini menggunakan solenoid sebagai pengunci pintu. Ichwan dkk. [7] membangun sebuah purwarupa aplikasi sistem kontrol peralatan listrik dengan Android sebagai solusi alternatif baru untuk mengontrol peralatan listrik dari jarak jauh. Sistem ini menggunakan ethernet shield untuk menghubungkan sistem ke jaringan internet. Anggriawan dan Candra [8] juga mengembangkan sistem pengaman pintu ruang kuliah dengan masukan sensor sidik jari. Untuk menjaga keamanan kunci ruangan, Hasta dan Rulliyanto [9] mengembangkan akses kontrol kotak kunci ruang kelas dengan gawai cerdas Android.

Sistem otomatisasi ruang ini dapat digunakan untuk meningkatkan keamanan ruangan dan otomatisasi presensi kuliah. Kajian ini bertujuan mengembangkan sistem kontrol pintu ruang kuliah ini menggunakan teknologi RFID seperti [2]-[5] dan diintegrasikan dengan aplikasi web sistem informasi presensi kuliah. Sistem ini dapat melakukan kontrol pada pintu dan membaca kartu RFID untuk autentikasi mahasiswa sehingga dapat digunakan untuk memasukkan data presensi ke basis data. Selain itu, awal kegiatan atau sesi kuliah dapat diidentifikasi berdasarkan kehadiran dosen.

Sistem diimplementasikan pada purwarupa 2 pintu ruang dengan dengan kontrol akses kartu tag RFID dosen dan identifikasi kartu RFID mahasiswa. Berbeda dengan Susanto dkk. [1] dan Chamdun dkk. [5] yang menggunakan mikrontroller Atmega 16 sebagai kontroler sistem, sistem yang diusulkan ini menggunakan Arduino Mega dengan mikrontroler ATmega 2560. Lebih lanjut, Eko dan Bobi [4] tidak menggunakan kontrol pintu pada autentikasi RFID seperti halnya kajian ini yang dapat mengontrol kunci pintu pada saat autentikasi dosen dan menutup otomatis setelah 30 menit. Selain itu, sistem yang diusulkan ini mengintegrasikan sistem presensi berbasis RFID dengan sistem informasi presensi dan penjadwalan kuliah sehingga proses autentikasi dosen dan mahasiswa, otorisasi penggunaan ruang kelas, dan pencatatan presensi terekam di basis data sistem informasi presensi.

\section{Metode Penelitian}

Pengembangan sistem ini dilakukan dalam 4 tahapan, yaitu identifikasi kebutuhan sistem, perancangan sistem, implementasi sistem, serta pengujian dan analisis sistem. Tahap pertama adalah 
melakukan identifikasi kebutuhan sistem untuk menyusun daftar kebutuhan fungsional dan non fungsional untuk sistem. Perancangan sistem otomatisasi ruang dilakukan berdasarkan dari data yang diperoleh dari tahap identifikasi kebutuhan sistem. Tahap perancangan ini meliputi perancangan perangkat keras dan perangkat lunak yang menghasilkan diagram blok perangkat keras dan diagram alir sistem. Sistem yang dikembangkan dapat melakukan kontrol pintu dan otomatisasi presensi. Hasil perancangan diimplementasikan dengan menggunakan komponen perangkat keras dan pemrograman perangkat lunak. Pengujian dilakukan untuk menguji sistem apakah mampu bekerja sesuai dengan spesifikasi yang telah ditentukan dengan memberikan masukan kasus perilaku-perilaku dan mengamati keluarannya.

Tahap implementasi melakukan perakitan perangkat keras dan pembuatan program yang ditanamkan pada sistem. Perangkat keras yang digunakan adalah pembaca RFID, papan Arduino Mega 2560 dengan mikrokontroler ATmega 2560, modul ethernet shield [8], [9], LCD, RTC [10], driver motor L298N, dan solenoid. Perangkat lunak bantu yang digunakan adalah Arduino IDE 1.6.13 yang berjalan pada sistem operasi Windows 10 untuk pemrograman perangkat keras. Selain itu, bahasa pemrograman PHP 5.5 digunakan untuk aplikasi web dan basis data MySQL untuk mengelola data hasil presensi dan jadwal kuliah. Tahap pengujian dan analisis sistem dilakukan dengan mengambil data pengamatan dalam uji coba perangkat keras dan perangkat lunak. Pengujian yang dilakukan adalah pengujian kinerja perangkat masukan, kinerja perangkat luaran, dan pengujian fungsional sistem.

Dalam kajian ini, sistem dibagi menjadi dua purwarupa dengan fungsi yang sama, namun mempunyai masukan kelas / ruangan yang berbeda pada setiap purwarupa. Purwarupa ini dipasang untuk mewakili dua kelas berbeda dan diharapkan dapat melakukan kontrol pintu dan otomatisasi presensi di ruang yang berkaitan. Fungsi kontrol pintu meliputi akses RFID yang dimiliki oleh dosen dan mahasiswa. Fungsi otorisasi presensi menggunakan RFID yang dimiliki oleh dosen dan mahasiswa yang dapat diakses sesuai dengan jadwal yang sudah ditentukan aplikasi web. Cara kerja sistem adalah dosen menempelkan kartu RFID apabila berhasil maka mata kuliah yang dituju akan aktif pintu akan terbuka serta mahasiswa bisa melakukan presensi. Mahasiswa dapat melakukan presensi dengan menempelkan kartu RFID.

Dalam operasionalnya, sistem harus selalu berkomunikasi dengan server sehingga membutuhkan koneksi internet. Pembacaan kartu RFID dosen dan mahasiswa dikirim ke server dan diautentikasi apakah sesuai dengan dengan jadwal yang ada. Data pembacaan kartu RFID mahasiswa juga dikirim ke server dan diautentikasi apakah mahasiswa terdaftar dalam mata kuliah yang diaktifkan oleh dosen. Gambar 1 merupakan diagram blok cara kerja sistem secara keseluruhan yang terdiri atas sistem presensi dan kontrol pintu serta aplikasi presensi berbasis web.

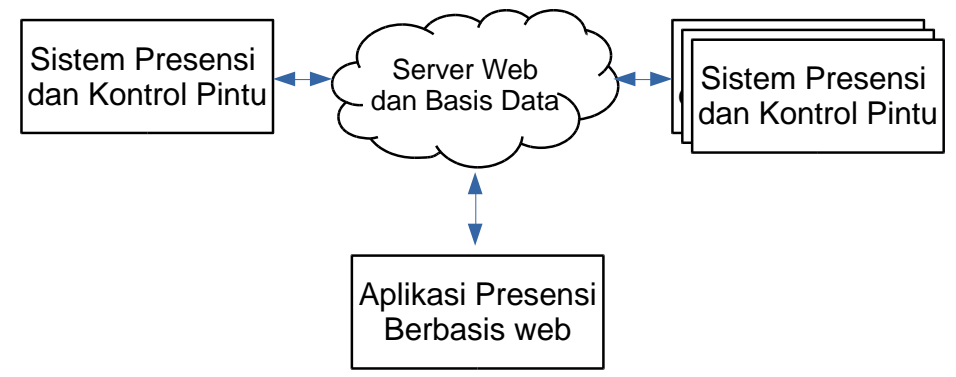

Gambar 1. Diagram blok sistem yang diusulkan.

Secara fungsional, sistem diharapkan mampu membuka pintu dengan masukan RFID setelah proses autentikasi dan otorisasi berhasil, mampu mengautentikasi dosen dan mahasiswa dengan masukan kartu RFID, mampu berkomunikasi dengan aplikasi web melalui koneksi internet menggunakan modul ethernet shield, dan mampu menyimpan data presensi mahasiswa ke basis data. Sistem mampu menampilkan hasil pembacaan kartu tag RFID pada LCD. Aplikasi web sistem informasi presensi mampu mengolah data dosen, mahasiswa,kelas, mata kuliah, jadwal, dan data presensi. 
Perangkat keras yang digunakan untuk membangun sistem presensi dan kontrol pintu ditunjukkan dalam diagram blok di Gambar 2. Pusat kontrol sistem menggunakan papan Arduino Mega2560 dengan mikrokontroler ATmega2560. Komponen yang terhubung dengan pusat kontrol ini adalah pembaca RFID MFRC522 sebagai pembaca kartu RFID dengan frekuensi 13.56 $\mathrm{MHz}$, ethernet shield sebagai media komunikasi ke jaringan internet LAN dan server basis data, LCD alphanumerik 16x2 karakter sebagai luaran tampilan dari sistem, solenoid yang berfungsi sebagai pengunci pintu yang dilengkapi pengendali motor L298N, RTC DS3231 untuk modul pewaktuan, dan tombol tekan sebagai pembuka pintu dari dalam ruangan. Sistem ini dijalankan dengan catu daya sebesar 9V $1 \mathrm{~A}$.

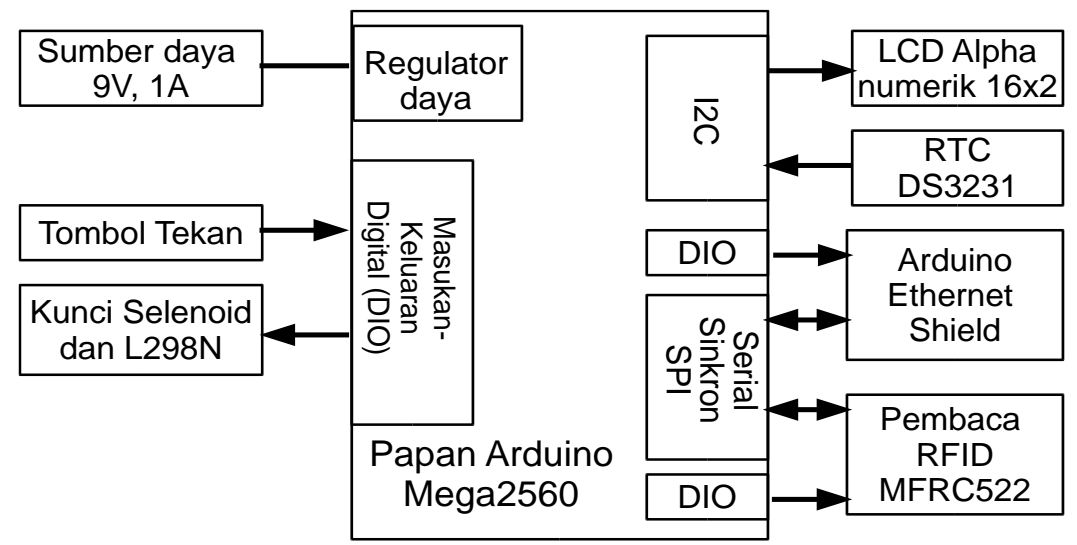

Gambar 2. Diagram blok perangkat keras sistem.

Sistem menggunakan pin-pin yang tersedia pada papan Arduino Mega 2560. Sepasang pin serial untuk $\mathrm{I}^{2} \mathrm{C}$, yaitu pin SDA dan SCL, digunakan untuk modul RTC dan LCD, dan empat pin digital sebagai keluaran ethernet shield (komunikasi serial) dan RFID MFRC522. Tabel 1 menunjukkan antarmuka pin Arduino dengan komponen sistem. Kolom keterangan menunjukkan fungsi dari komponen dalam sistem.

Tabel 1. Antarmuka pin Arduino Mega2560 dengan komponen sistem.

\begin{tabular}{|c|c|c|}
\hline Pin Arduino & Antarmuka Pin Komponen & Keterangan \\
\hline 2 & Masukan tombol tekan & $\begin{array}{l}\text { Masukan pembuka pintu } \\
\text { dari dalam ruangan }\end{array}$ \\
\hline 8 & Driver Motor L298N & $\begin{array}{l}\text { Mengendalikan kunci } \\
\text { pintu selenoid }\end{array}$ \\
\hline 20 (SDA) & SDA RTC DS3231 dan SDA LCD & Bus I2C digunakan \\
\hline 21 (SCL) & SCL RTC DS3231 dan SCL LCD & bersama RTC dan LCD \\
\hline 5 & RST RFID & Pin DIO untuk reset RFID \\
\hline 50 & MISO RFID, MISO Ethernet Shield & Bus serial sinkron SPI \\
\hline 51 & MOSI RFID, MOSI Ethernet Shield & digunakan bersama antara \\
\hline 52 & SCK RFID, SCK Ethernet Shield & $\begin{array}{l}\text { RFID MRFC522 dan } \\
\text { Ethernet Shield }\end{array}$ \\
\hline 53 & SS RFID & $\begin{array}{l}\text { Masukan pemilih untuk } \\
\text { RFID MRFC522 }\end{array}$ \\
\hline 10 & SS Ethernet Shield & $\begin{array}{l}\text { Masukan pemilih untuk } \\
\text { Ethernet Shield }\end{array}$ \\
\hline
\end{tabular}

Perancangan perangkat lunak meliputi tahap pembuatan algoritme program pada mikrokontroler dan aplikasi web sistem informasi. Perangkat lunak mikrokontroler berupa program yang mengatur perangkat keras untuk membaca masukan dari kartu tag RFID sesuai penjadwalan yang sudah ditetapkan, membaca waktu sesuai dengan RTC yang terpasang, menampilkan data pada LCD, menghubungkan sistem ke server web melalui modul ethernet shield, melakukan autentikasi, dan memberikan umpan balik ke sistem serta mengendalikan 
aktuator kunci pintu selenoid. Desain sistem perangkat lunak untuk presensi dan pembukaan kelas dinyatakan dalam diagram FSM (finite state machine) di Gambar 3.

Pertama kali, sistem melakukan inisialisasi dengan keadaan locked_door dosen. Jika RFID terdeteksi, maka keadaan berubah ke auth_dosen. Sistem akan melakukan autentikasi terhadap dosen berdasarkan ID dan jadwal kuliah. Apabila berhasil, maka keadaan berubah ke unlocked_door dan kelas aktif. Apabila gagal, maka keadaan kembali ke locked_door untuk menunggu kartu RFID. Jika kelas aktif, mahasiswa diminta untuk melakukan presensi berdasarkan kartu RFID. Jika kartu RFID mahasiswa telah terbaca, maka keadaan berubah ke auth_mhs. Jika autentikasi mahasiswa gagal, maka keadaan kembali ke unlocked_door untuk menunggu presensi mahasiswa. Jika autentikasi berhasil, maka data presensi mahasiswa dikirimkan di basis data. Jika waktu telah lebih dari 30 menit, maka keadaan kembali ke locked door untuk mengunci pintu.

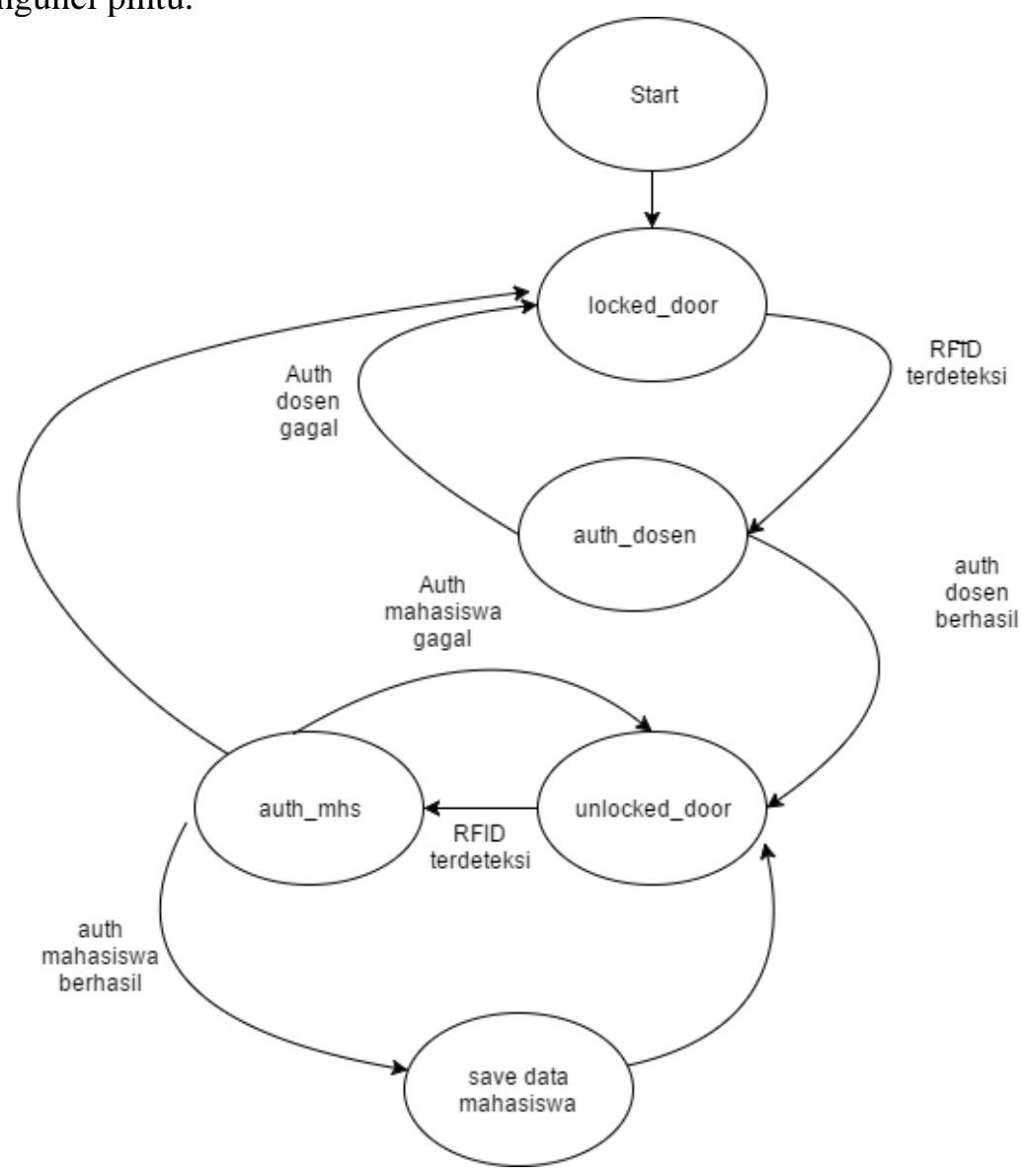

Gambar 3. Diagram FSM perangkat keras sistem untuk proses presensi.

Perancangan web untuk aplikasi presensi ini memperhatikan sasaran pengguna aplikasi ini, yaitu administrator akademik program studi. Kajian ini mengambil kasus program studi di Departemen Sistem Komputer, Universitas Diponegoro. Perancangan sistem presensi ini menggunakan pemodelan UML (Unified Modeling Language) untuk menentukan, memvisualisasikan, membangun, dan mendokumentasikan komponen-komponen dari sistem perangkat lunak. Hasil perancangan sistem ini adalah berupa diagram use case dan model data berupa ERD (Entity Relational Diagram).

Diagram use case digunakan untuk menggambarkan secara ringkas hubungan antara kasus penggunaan, aktor, dan sistem. Sistem dalam kajian ini memiliki aktor, yaitu admin program studi, yang berperan mengelola keseluruhan data yang ada di dalam aplikasi sistem informasi presensi melalui halaman web, yaitu meliputi kelola data presensi, kelas, jadwal,mata kuliah, 
dosen, mahasiswa. Gambar 4 menunjukan diagram use case aplikasi sistem informasi presensi ini.

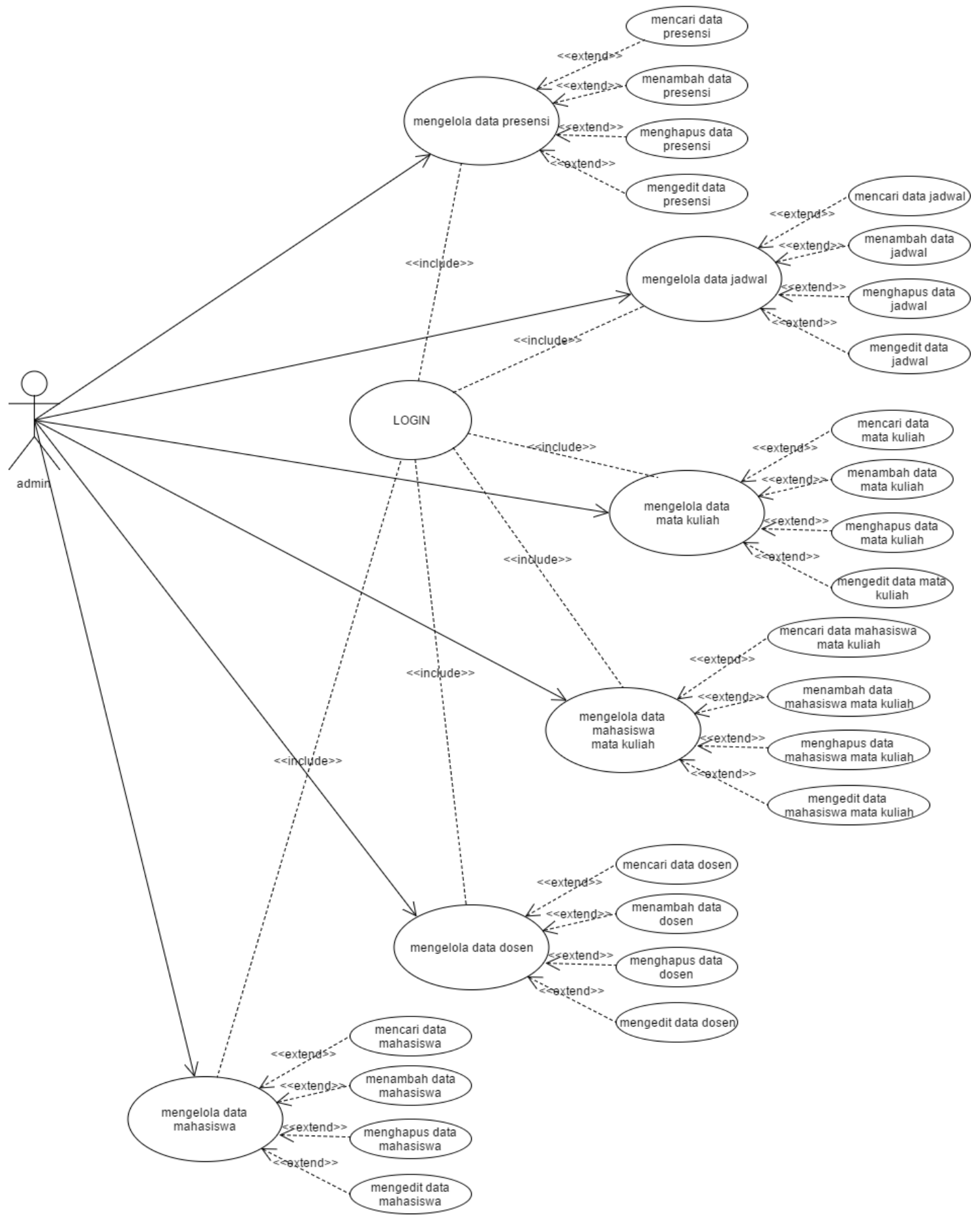

Gambar 4. Diagram use case aplikasi sistem informasi presensi kuliah.

Model data untuk menggambarkan data dalam hal entitas dan relasi data dalam sistem ini dinyatakan dalam ERD di Gambar 5. ERD tersebut menampilkan skema saling keterkaitan antara tabel satu dengan tabel yang lainnya. Ada enam tabel yang saling terikat dan dikelola oleh user, yaitu administrator program studi, pada $t b \_u s e r$. Tabel $t b \_d o s e n$ mempunyai keterkaitan dengan $t b \_m a k u l$ karena peran dosen sebagai pengampu mata kuliah. Tabel tb_makul memiliki relasi dengan $t b \_m h s m a k u l$ karena dalam sebuah mata kuliah terdapat para mahasiswa yang mengambil 
mata kuliah tersebut. Tabel $t b \_m a k u l$ dan $t b \_k e l a s$ juga memiliki relasi dengan $t b \_j a d w a l$. Tabel tb_mhs mempunyai relasi dengan dengan tb_mhsmakul karena untuk mengidentifikasi mahasiswa mengambil mata kuliah tertentu. Tabel tb_presensi mempunyai keterkaitan dengan $t b \_m h s$ dan $t b \_m a k u l$ karena di dalam tabel tersebut terdapat data mahasiswa dan kode mata kuliah.

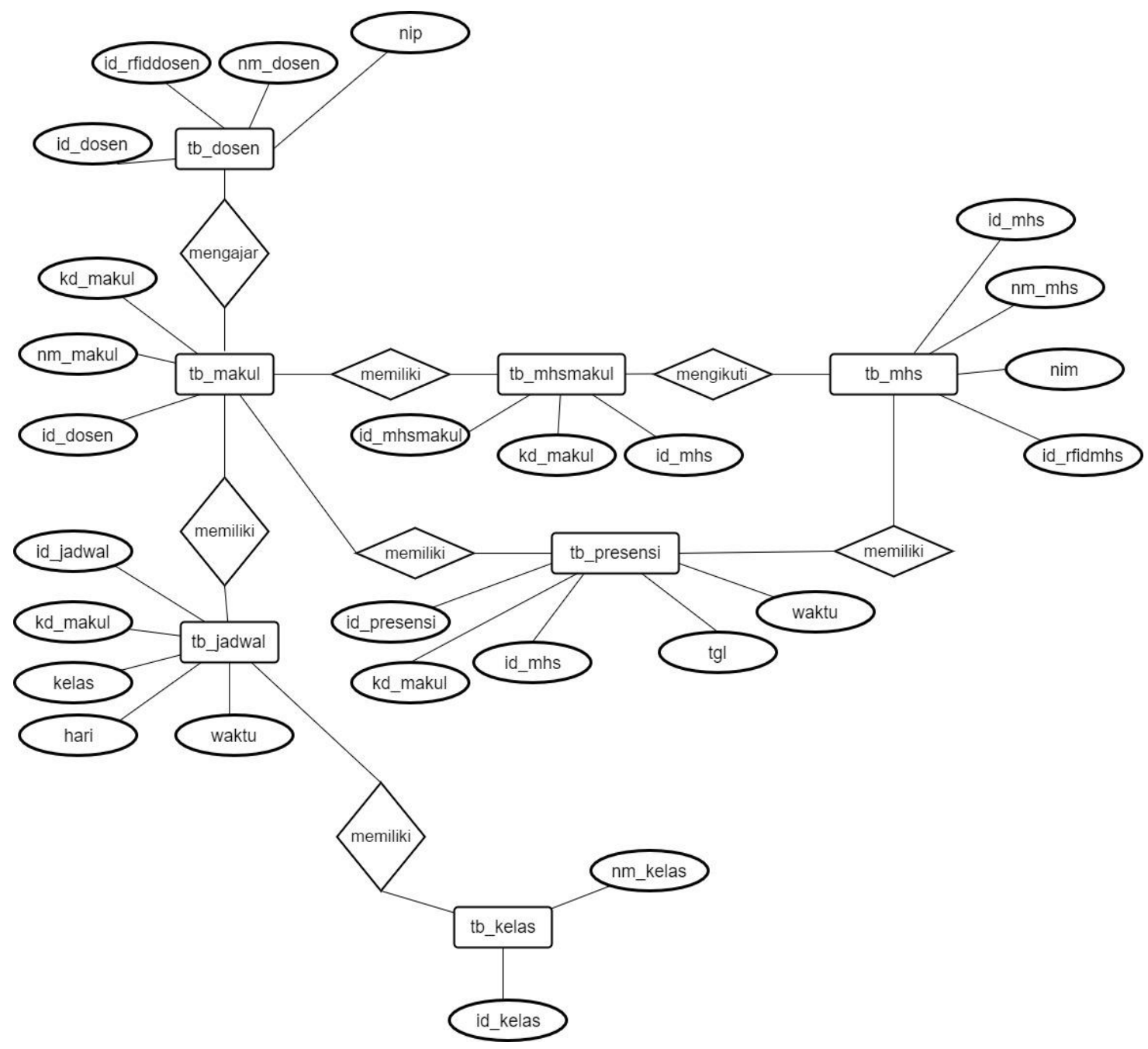

Gambar 5. ERD sistem informasi presensi kuliah.

\section{Hasil dan Pembahasan}

Implementasi sistem ini menggunakan papan Arduino Mega 2560 sebagai pusat kontrol dari sistem. Sistem utama terhubung dengan komponen masukan dan keluaran, yaitu RFID MFRC522, RTC sebagai pewaktu, LCD 16x2 sebagai penampil luaran, solenoid sebagai pengunci pintu, dan modul ethernet shield sebagai penghubung ke server. Implementasi sistem adalah berupa sebuah purwarupa ruangan yang terdiri dari 2 buah pintu memiliki sistem sendiri. Pada sistem utama terdapat ethernet yang langsung disambungkan ke Arduino Mega 2560 dan sebuah papan sirkuit elektronik sebagai tempat komponen-komponen sistem saling terhubung untuk menjadi sebuah sistem perangkat keras yang dapat secara mudah dihubungkan dengan papan kontroler. Gambar 6 merupakan bentuk purwarupa yang terdiri dari 2 buah ruang dengan masing-masing ruang memiliki sistem sendiri. 


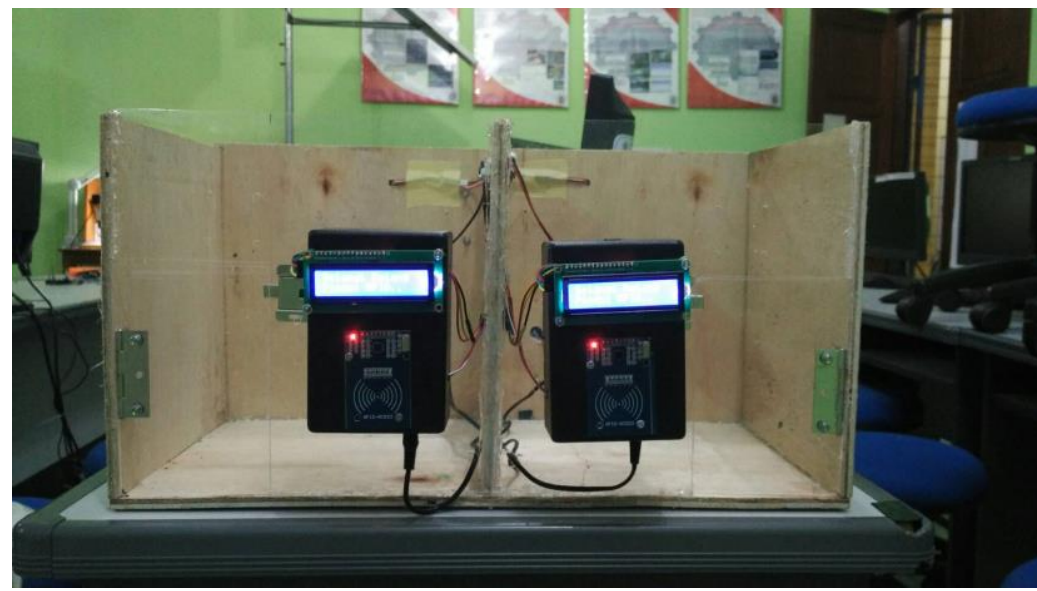

Gambar 6. Purwarupa sistem untuk dua ruang kuliah.

Hasil implementasi perangkat lunak dinyatakan tampilan halaman aplikasi pada sisi server yang telah dibangun. Aplikasi ini tersimpan pada komputer server dengan alamat IP privat, yaitu 10.42.14.215. Aplikasi ini diakses dengan pada penjelajah web dengan alamat URL lokal 10.42.15.215/presensirfid. Setelah berhasil login, pengguna administrator akademik program studi dapat melakukan aktivitas, di antaranya meliputi pengelolaan data presensi (Gambar 7), data jadwal (Gambar 8), data mata kuliah (Gambar 9), data mahasiswa per mata kuliah (Gambar 10), data kelas (Gambar 11), data dosen (Gambar 12), dan data mahasiswa (Gambar 13).

Halaman Data Presensi menampilkan data presensi yang telah masuk dari sistem mikrokontroler yang dilengkapi dengan fungsi untuk menambah, mengubah, dan menghapus data presensi yang ada. Halaman Data Jadwal menampilkan jadwal kuliah aktif dalam satu semester yang dilengkapi dengan fungsi untuk menambah, mengubah, dan menghapus data jadwal. Halaman Data Mata Kuliah menampilkan mata kuliah yang ditawarkan di kurikulum program studi yang dilengkapi dengan fungsi untuk menambah, mengubah, dan menghapus data presensi yang ada.

Halaman Data Mahasiswa Mata Kuliah menampilkan data mahasiswa yang mengambil mata kuliah yang dilengkapi fungsi untuk menambah, mengubah, dan menghapus data pengambilan mata kuliah. Halaman Data Kelas menampilkan data kelas yang tersedia dan dilengkapi dengan fungsi untuk menambah, mengubah, dan menghapus kelas. Halaman Data Dosen menampilkan data dosen yang mengajar di program studi dan dilengkapi fungsi menambah, mengubah, dan menghapus data dosen. Halaman Data Mahasiswa menampilkan data mahasiswa yang terdaftar di program studi dan dilengkapi fungsi untuk menambah, mengubah, dan menghapus mahasiswa.

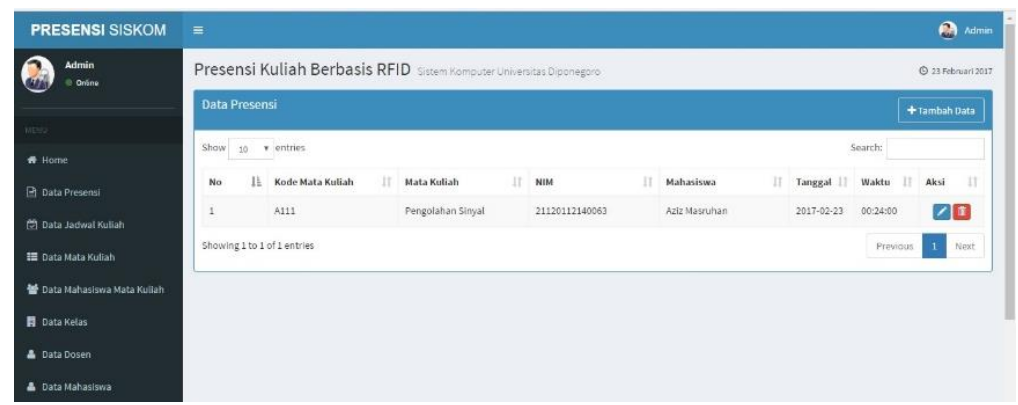

Gambar 7. Tampilan halaman presensi aplikasi sistem informasi presensi. 


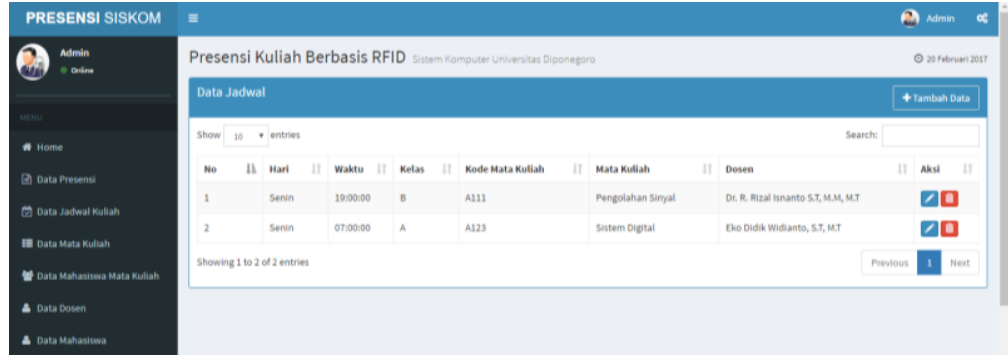

Gambar 8. Tampilan halaman jadwal aplikasi sistem informasi presensi.

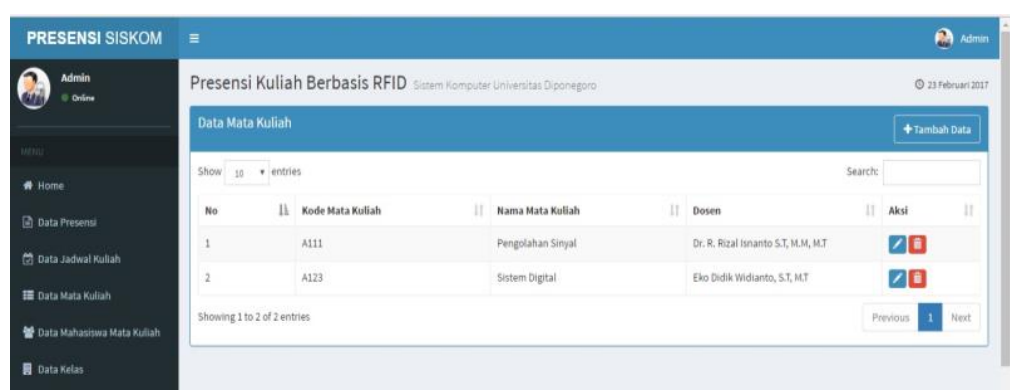

Gambar 9. Tampilan halaman mata kuliah aplikasi sistem informasi presensi.

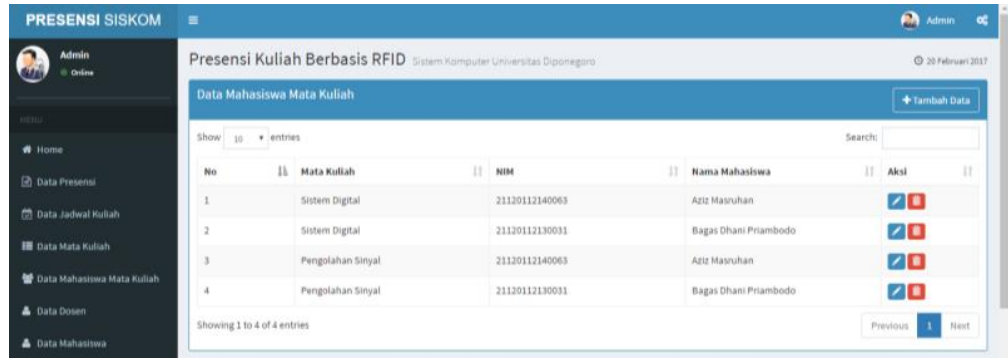

Gambar 10. Tampilan halaman mahasiswa mata kuliah aplikasi sistem informasi presensi.

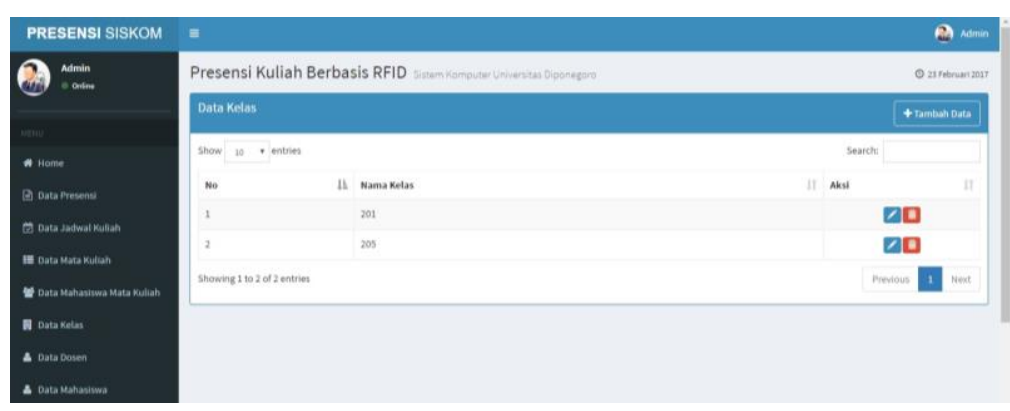

Gambar 11. Tampilan halaman kelas aplikasi sistem informasi presensi.

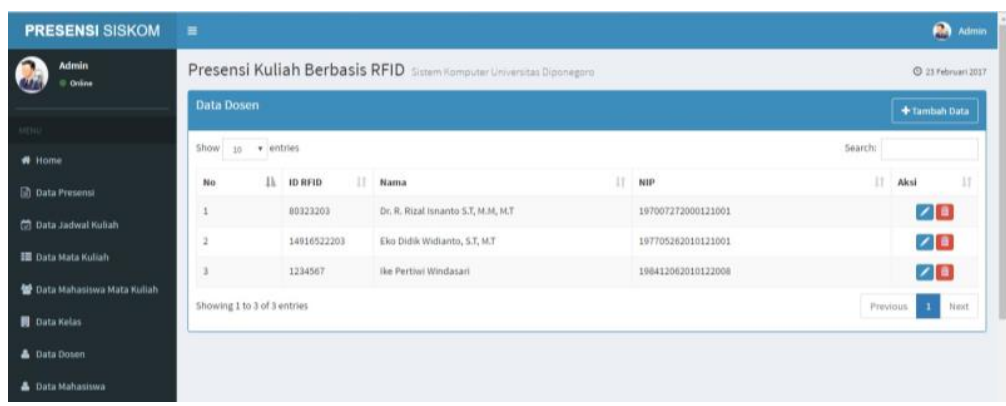

Gambar 12. Tampilan halaman dosen aplikasi sistem informasi presensi. 


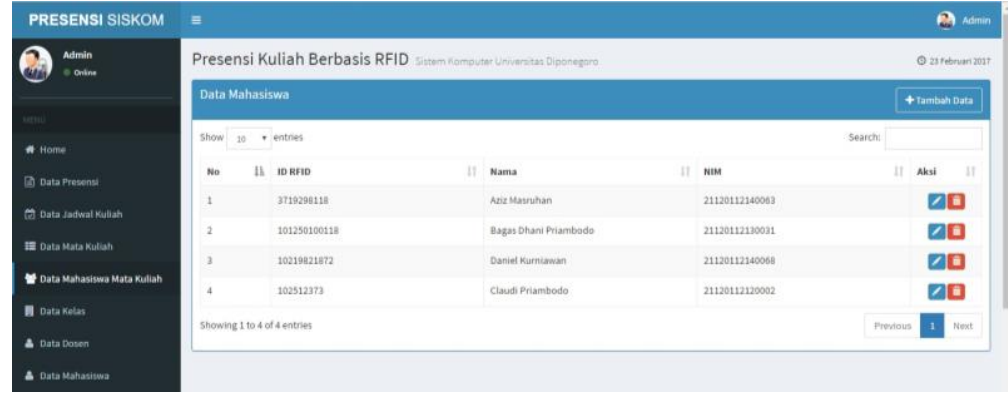

Gambar 13. Tampilan halaman dosen aplikasi sistem informasi presensi.

Pengujian sistem ini dilakukan terhadap sistem presensi berbasis mikrokontroler dan pengujian aplikasi web. Pengujian pada mikrokontroler terdiri dari pengujian pembacaan RFID, akurasi RTC, dan pengujian fungsional sistem presensi kuliah dan kontrol pintu ruangan menggunakan RFID. Pengujian pada aplikasi sistem informasi presensi di web menguji fungsional seluruh fungsi yang ada secara kotak hitam (black box).

Pengujian RFID dilakukan untuk menguji kemampuan fungsional sistem dalam mendeteksi ID kartu tag dan kinerja kemampuan jarak pembacaannya. Pengujian deteksi ID kartu tag dilakukan dengan mendekatkan kartu RFID ke pembaca dan hasil pembacaan kartu RFID dilihat di tampilan serial monitor Arduino. Gambar 14 menunjukkan hasil pengujian pembacaan kartu RFID. Pembacaan kartu RFID oleh sistem dapat dilakukan dengan baik. Hal tersebut menunjukkan bahwa perangkat keras dan perangkat lunak di Arduino Mega dapat bekerja dengan baik.

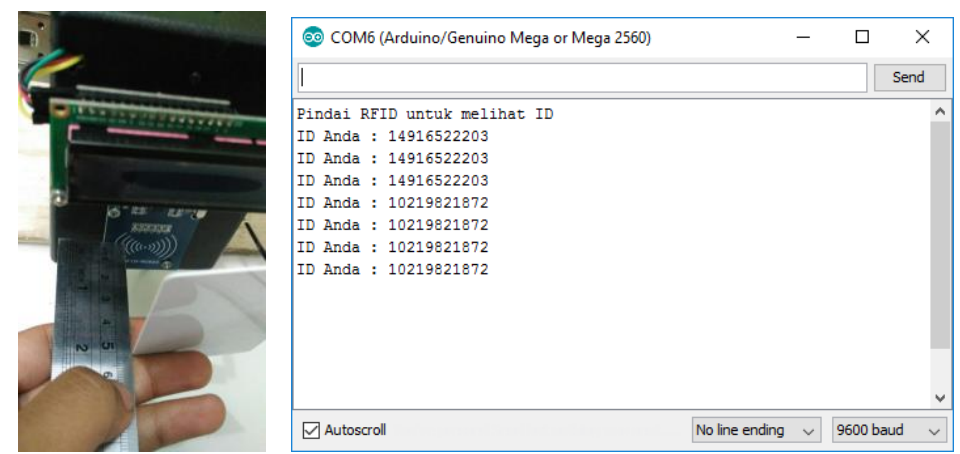

Gambar 14. Hasil pengujian pembacaan tag RFID pada serial monitor.

Pengujian jarak pembacaan RFID dilakukan untuk mengetahui jarak maksimal RFID dalam mendeteksi kartu RFID. Resolusi pembacaan yang dilakukan dalam pengujian adalah $1 \mathrm{~cm}$. Alat ukur yang digunakan adalah mistar. Kartu RFID diletakkan dalam jarak yang sudah ditentukan dan ID dibaca oleh sistem (Gambar 14). Pengujian kartu RFID dilakukan 10 kali untuk tiap jarak yang telah ditentukan. Tabel 2 menunjukkan hasil dari pengujian jarak pembacaan. Kartu dinyatakan terdeteksi jika ID yang tampil di serial monitor sama dengan ID dalam kartu untuk semua pengujian. Kemampuan pembacaan sistem terhadap kartu RFID adalah maksimal $4 \mathrm{~cm}$. Hal ini menunjukkan kemampuan pembacaan pembaca RFID yang digunakan, yaitu MFRC522.

Tabel 2. Hasil pengujian jarak pembacaan kartu RFID.

\begin{tabular}{cc}
\hline Jarak $(\mathbf{c m})$ & Pembacaan RFID Tag \\
\hline 0 & Terdeteksi \\
1 & Terdeteksi \\
2 & Terdeteksi \\
3 & Terdeteksi \\
4 & Terdeteksi \\
5 & Tidak terdeteksi \\
\hline
\end{tabular}

ISSN (e): 2540-9123

ISSN (p): 2502-1982 
Pengujian RTC DS3231 dilakukan dengan membandingkan pembacaan waktu pada RTC DS3231 dengan waktu pada laptop. Pembacaan waktu ini diperlukan karena terkait dengan jadwal yang tersetel di aplikasi web sistem informasi presensi dengan yang terbaca di sistem pembaca presensi. Tabel 3 menunjukkan hasil pengujian untuk pembacaan waktu pada RTC DS3231 di sistem pembaca presensi dengan laptop. Hasil tersebut menunjukkan perbedaan pengaturan pewaktuan awal, yaitu waktu pada RTC pukul 00:12:40 dan waktu pada laptop pukul 00:12:44 dengan $\Delta \mathrm{t} 0$ sebesar 4 detik. Kesalahan $\Delta \mathrm{t} 0$ ini adalah kesalahan offset, yang dapat diatasi dengan melakukan setelan di RTC. Pengujian selama 2 hari menunjukkan nilai offset ini konsisten sehingga rata-rata penyimpangan pembacaan, $\Delta \mathrm{t}-\Delta \mathrm{t} 0$, sebesar 0 yang menunjukkan RTC DS3231 telah bekerja dengan baik.

Tabel 3. Hasil pengujian pembacaan waktu oleh RTC DS3231.

\begin{tabular}{cccccc}
\hline \multirow{2}{*}{ No } & \multicolumn{2}{c}{ RTC DS3231 } & \multicolumn{2}{c}{ Laptop } & \multirow{2}{*}{ st (detik) } \\
\cline { 2 - 4 } & Tanggal & Jam & Tanggal & Jam & \\
\hline 1 & $18 / 02 / 20$ & $00: 12: 40$ & $18 / 02 / 20$ & $00: 12: 44$ & 4 \\
2 & $18 / 02 / 20$ & $00: 15: 32$ & $18 / 02 / 20$ & $00: 15: 36$ & 4 \\
3 & $18 / 02 / 20$ & $00: 17: 10$ & $18 / 02 / 20$ & $00: 17: 14$ & 4 \\
4 & $18 / 02 / 20$ & $00: 59: 12$ & $18 / 02 / 20$ & $00: 59: 14$ & 4 \\
5 & $18 / 02 / 20$ & $01: 02: 01$ & $18 / 02 / 20$ & $01: 02: 05$ & 4 \\
6 & $18 / 02 / 20$ & $08: 34: 09$ & $18 / 02 / 20$ & $08: 34: 13$ & 4 \\
7 & $19 / 02 / 20$ & $10: 45: 24$ & $19 / 02 / 20$ & $10: 45: 28$ & 4 \\
8 & $19 / 02 / 20$ & $10: 56: 30$ & $19 / 02 / 20$ & $10: 56: 34$ & 4 \\
9 & $19 / 02 / 20$ & $17: 56: 22$ & $19 / 02 / 20$ & $17: 56: 26$ & 4 \\
10 & $19 / 02 / 20$ & $19: 31: 16$ & $19 / 02 / 20$ & $19: 31: 20$ & 4 \\
\hline
\end{tabular}

Pengujian keseluruhan sistem dilakukan secara fungsional dengan menggabungkan seluruh perangkat presensi dengan mikrokontroler dan aplikasi sistem informasi presensi. Hasil pengujian menunjukkan sistem mikrokontroler mampu berjalan dengan baik dan mampu berinteraksi dengan aplikasi sistem informasi presensi sesuai spesifikasi yang telah ditentukan. Sistem telah mampu melakukan pembacaan kartu RFID, autentikasi data dosen dan mahasiswa terhadap data di aplikasi sistem informasi presensi, melakukan pengecekan otorisasi kelas berdasarkan autentikasi dosen dan jadwal kuliah, membuka dan mengunci pintu secara otomatis, serta melakukan pencatatan kehadiran mahasiswa yang hadir ke basis data berdasarkan pembacaan kartu RFID mahasiswa. Sistem juga mampu menampilkan tulisan kelas aktif dan status presensi mahasiswa di layar LCD. Keadaan kunci selenoid dan tampilan LCD ditunjukkan dalam Gambar 15. Aplikasi sistem informasi sistem presensi berbasis RFID ini telah dapat mengolah data dosen, mahasiswa, kelas, jadwal, dan data presensi dengan baik. Hasil pengujian sistem dan kotak hitam semua fungsi aplikasi dinyatakan dalam lampiran.
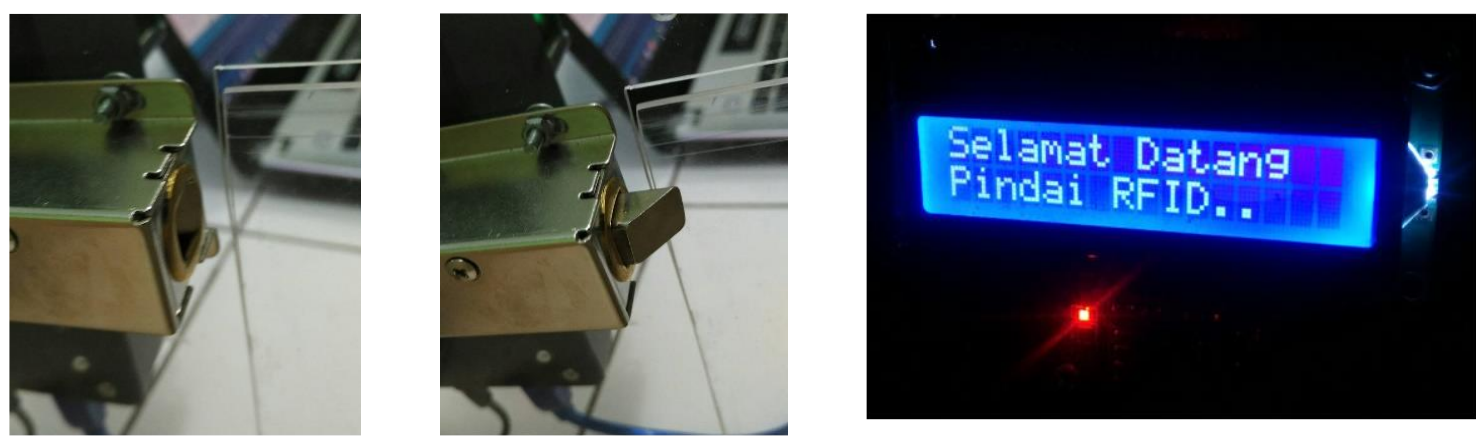

Gambar 15. Keadaan kunci selenoid dan tampilan.

ISSN (e): 2540-9123

ISSN (p): 2502-1982 


\section{Kesimpulan}

Sistem kontrol pintu ruang dan presensi kuliah mampu melakukan mencocokan kartu RFID dosen dengan data jadwal dan mencocokan kartu mahasiswa dengan data mahasiswa di mata kuliah yang terjadwal pada basis data. Sistem mampu mengontrol pembukaan pintu ruang kuliah dan proses dimulainya perkuliahan berdasarkan autentikasi dan otorisasi dosen. Status presensi dosen dan mahasiswa telah dapat ditampilkan di layar LCD. Proses pembacaan data dosen dan mahasiswa ini terintegrasi dengan aplikasi sistem informasi presensi yang mengolah data presensi, jadwal, mata kuliah, mahasiswa mata kuliah, dosen dan mahasiswa. Pembacaan kartu RFID dapat dilakukan sampai jarak $4 \mathrm{~cm}$. Perbedaan waktu yang konsisten sebesar 4 detik saat pengujian antara sistem presensi dan aplikasi web dapat diatasi dengan menyetel offset RTC DS3231 di sistem presensi.

\section{Daftar Referensi}

[1] R. Susanto, A. Ananta, A. Santoso, dan M. Trianto, "Sistem Absensi Berbasis RFID," J. Tek. Komput., vol. 17, no. 9, pp. 67-74, 2009.

[2] V. O. Panggabean dan F. Pandi, "Sistem Absensi Berbasis Radio Frequency Identification (RFID) Pada Mikroskil,” JSM STMIK Mikroskil, vol. 14, no. 2, pp. 129-138, 2013.

[3] P. Purwanti dan R. Romataliga, "Implementasi RFID Pada Sistem Presensi Dan Display Data Pengguna Id-Tag,” J. Poli-Teknologi, vol. 11 Nomor 2, no. 1, pp. 1-9, 2012.

[4] B. S. Eko dan K. Bobi, "Perancangan Sistem Absensi Kehadiran Perkuliahan dengan Menggunakan Radio Frequency Identification ( RFId )," CoreIT,Vol.1,No.2, Desember 2015, vol. 1, no. 2, pp. 44-49, 2015.

[5] M. Chamdun, A. F. Rochim, dan E. D. Widianto, "Sistem Keamanan Berlapis pada Ruangan Menggunakan RFID (Radio Frequency Identification) dan Keypad untuk Membuka Pinta Secara Otomatis," J. Teknol. dan Sist. Komput., vol. 2, no. 3, pp. 187-194, 2014.

[6] M. R. Asad, O. D. Nurhayati, dan E. D. Widianto, "Sistem Pengamanan Pintu Rumah Otomatis via SMS Berbasis mikrokontroler ATMega328P," J. Teknol. dan Sist. Komput., vol. 3, no. 1, pp. 1-7, 2016.

[7] M. Ichwan, M. G. Husada, dan M. Iqbal Ar Rasyid, "Pembangunan Prototipe Sistem Pengendalian Peralatan Listrik pada Platform Android," J. Inform., vol. 4, no. 1, pp. 1325, 2013.

[8] R. Anggriawan dan O. Candra, "Rancang Bangun Pengaman Pintu Ruang Kuliah Menggunakan Sensor Fingerfrint Berbasis Arduino Mega2560," Jurnal Teknik elektro dan Vokasional, vol. 6, no. 1, pp. 25-34, 2020.

[9] H. Hasta dan R. Rulliyanto, "Aplikasi Teknologi Komunikasi Wireless Berbasis Zigbee Pada Sistem Kontrol dan Monitoring Ruangan Kelas," Jurnal Ilmiah Giga, vol. 18, no. 2, pp. 61-72, 2015.

[10] M. Arifin, E. F. Firrizqi, dan A. Sani, "Akses Kontrol Kotak Kunci Ruang Kelas Berbasis Smartphone Android," Jurnal Integrasi, vol. 11, no. 1, pp. 63-67, 2019.

[11] P. Mandarani, "Perancangan Dan Implementasi User Interface Berbasis Web Untuk Monitoring Suhu, Kelembaban Dan Asap Pada Ruangan Berbeda Dengan Memanfaatkan Jaringan Local Area Network," J. TEKNOIF, vol. 2, no. 2, pp. 37-42, 2014.

[12] Maxim Integrated, "Datasheet DS3231 Extremely Accurate I2C-Integrated RTC/TCXO/Crystal," 2015 [online]. 